\title{
Talking about education: exploring the significance of teachers' talk for teacher agency
}

\section{Gert Biesta, Mark Priestley \& Sarah Robinson}

To cite this article: Gert Biesta, Mark Priestley \& Sarah Robinson (2017) Talking about education: exploring the significance of teachers' talk for teacher agency, Journal of Curriculum Studies, 49:1, 38-54, DOI: 10.1080/00220272.2016.1205143

To link to this article: http://dx.doi.org/10.1080/00220272.2016.1205143
2 (c) 2017 The Author(s). Published by Informa UK Limited, trading as Taylor \& Francis Group

曲 Published online: 05 Jan 2017.

\section{$\sqrt{6}$ Submit your article to this journal $\square$}

LII Article views: 543

Q View related articles ¿ک

\section{View Crossmark data $\nearrow$}




\title{
Talking about education: exploring the significance of teachers' talk for teacher agency
}

\author{
Gert Biesta $^{a}$ (D), Mark Priestley ${ }^{b}$ and Sarah Robinson ${ }^{c}$ \\ ${ }^{a}$ Department of Education, Brunel University London, UK; ${ }^{b}$ Faculty of Social Sciences, University of Stirling, UK; \\ 'Centre for Teaching Development and Digital Media, Aarhus University, Denmark
}

\begin{abstract}
The interest in teachers' discourses and vocabularies has for a long time been studied under the rubric of knowledge, most notably teachers' professional knowledge. This interest can be traced back to Shulman's distinction between different kinds of teacher knowledge and Schwab's interest in the role of practical reasoning and judgement in teaching. Within the research, a distinction can be found between a more narrow approach that focuses on teachers' propositional or theoretical knowledge and a more encompassing approach in which teachers' knowledge is not only the knowledge for teachers generated elsewhere, but also the knowledge of teachers. This is the 'stock of knowledge' gained from a range of sources and experiences, including teachers' ongoing engagement with the practice of teaching itself. In this paper, we focus on the role of teachers' talk in their achievement of agency. We explore how, in what way and to what extent such talk helps or hinders teachers in exerting control over and giving direction to their everyday practices, bearing in mind that such practices are not just the outcome of teachers' judgements and actions, but are also shaped by the structures and cultures within which teachers work.
\end{abstract}

\section{KEYWORDS}

Teacher knowledge; teachers' vocabularies; teachers' talk; teacher professionalism; teacher agency

\section{Introduction: teacher agency and teacher talk}

The interest in teachers' discourses and vocabularies has for a long time been studied under the rubric of knowledge, most notably teachers' professional knowledge. This interest can be traced back to Shulman's distinction between different kinds of teacher knowledgecontent knowledge, general knowledge, curriculum knowledge, pedagogical content knowledge, knowledge of learners and their characteristic, knowledge of educational contexts, knowledge of educational ends, purposes, and values and their philosophical and historical grounds (see Shulman, 1986, p.8)—and Schwab's interest in the role of practical reasoning and judgement in teaching (see Biesta, 2013; Schwab, [1970] 2013). This work is itself embedded within wider discourses about knowledge and judgement in a broad range of professional practices (see, e.g. Eraut, 1994; Schön, 1983, 1987). 
Within the research on teacher knowledge a distinction can be found between a more 'narrow' approach that focuses on teachers' propositional or theoretical knowledge-nowadays often connected to scientifically validated evidence about 'what works' (see Biesta, 2007 for an overview and critical discussion) - and a more 'encompassing' approach in which teachers' knowledge is not only the knowledge for teachers generated elsewhere, but also the knowledge of teachers (for the distinction see Fenstermacher, 1994). This is the'stock of knowledge' gained from a range of sources and experiences, including teachers' ongoing engagement with the practice of teaching itself (see, e.g. Ben-Peretz, 2011). Whereas some research has tried to move away from the personal and the experiential towards the construction of a common or shared 'knowledge base' for teaching (e.g. Verloop, Van Driel, \& Meijer, 2001), other research has explicitly stayed with teachers' edge' (Connelly \& Clandinin, 1988) in order to deepen understanding of the complexities and significance of such embodied practical knowledge. This work has taken a particular interest in the narrative dimensions of such knowledge (see Connelly \& Clandinin, 1988, see also Goodson, Biesta, Tedder, \& Adair, 2010).

Our interest in this paper is on the role of teachers' talk in their achievement of agency. We are interested, in other words, in how, in what way and to what extent such talk helps or hinders teachers in exerting control over and giving direction to their everyday practices, bearing in mind that such practices are not just the outcome of teachers' judgements and actions, but are also shaped by the structured and cultures within which teachers work. The paper builds on our research into the conditions that shape and support teacher agency (see Biesta, Priestley, \& Robinson, 2015; Priestley, Biesta, Philippou, \& Robinson, 2015; Priestley, Biesta, \& Robinson, 2015a, 2015b). The particular context in which we raised these questions was the implementation of Curriculum for Excellence, a reform of the Scottish education system for children and young people aged 3 to 18 that explicitly sought to enhance the agency of teachers in the development and enactment of curriculum (see Priestley \& Biesta, 2013). Curriculum for Excellence was developed during the first decade of the twenty-first century, and implementation started from the 2010 to 2011 school year onwards (see http://educationscotland.gov.uk).

We conducted small-scale ethnographic research within a single education authority in Scotland, in one primary school and two secondary schools. Participants comprised two experienced classroom teachers plus a single senior line manager in each school, all of whom were interviewed at least once, and in most cases three or more times. Data were generated over three distinct phases, following an iterative design where each phase was partially determined by the findings of the previous phase. Data collection involved observation; semi-structured individual and group interviews, including, at the start of the project, a personal and professional history interview; analysis of key policy texts; and teacher network mapping. Project researchers spent several weeks in total in each setting, for example, conducting interviews and leading group sessions. Project data were analysed using a set of codes derived from the teacher agency model discussed in the next section, which allowed us to categorize findings according to the key concepts surrounding agency.

\section{Teacher agency and teachers' talk: an ecological approach}

Against the tendency to think of agency as a capacity or ability individuals possess, we have pursued an ecological understanding of agency that focuses on the question how agency 
is achieved in concrete settings and under particular ecological conditions and circumstances (Biesta \& Tedder, 2006). This ecological view of agency sees agency as an emergent phenomenon of the ecological conditions through which it is enacted, highlighting

that actors always act by means of their environment rather than simply in their environment [so that] the achievement of agency will always result from the interplay of individual efforts, available resources and contextual and structural factors as they come together in particular and, in a sense, always unique situations. (Biesta \& Tedder, 2007, p. 137)

Agency is therefore both a temporal and a relational phenomenon; it is something that occurs over time and is about the relations between actors and the environments in and through which they act.

In our understanding of agency we draw on Emirbayer and Mische (1998), who have sought to theorise agency in such a way as to overcome the theoretical one-sidedness of existing theories. Such theories tend to focus either on routine - that is, on the experience and expertise teachers bring to their work - or on purpose - that is on the orientations that guide teachers' work-or on judgement - that is, on the decisions teachers make about what to do and how to do it in the here and now. Emirbayer and Mische make a case for a theory of agency that encompasses the dynamic interplay between these three dimensions and which takes into consideration 'how this interplay varies within different structural contexts of action' (Emirbayer \& Mische, 1998, p. 963). For this reason, they suggest that the achievement of agency should be understood as a configuration of influences from the past, orientations towards the future and engagement with the present. They refer to these three dimensions as the iterational, the projective and the practical-evaluative dimension, respectively. ${ }^{1}$

Taking an ecological approach to teacher agency and acknowledging that in the achievement of agency past, future and present all play a role, begins to suggest that there are quite a lot things that may affect-positively or negatively — the ways in which and the extent to which teachers achieve agency in the always concrete and unique settings in which they work. In other publications we have explored the role of values and beliefs (Biesta et al., 2015), the impact of cultures of performativity (Priestley, Robinson, \& Biesta, 2012) and the intersections between teacher agency and curriculum policy and practice (Priestley, Biesta, \& Robinson, 2013). What cuts across many of these discussions is the role played by the vocabularies teachers deploy-or in more mundane terms: teachers talk—not only because such vocabularies allow teachers to make sense of the situations they are in, but also because they shape their expectations and ambitions, their views about what is possible and what not, both with regard to themselves and their actions, and with regard to the colleagues they work with and the students they work for. We thus see teachers' talk as an important resource for the achievement of agency. In what follows we seek to make visible what this resource looks like, and also where it comes from and how it functions in teachers' speaking, thinking and doing. The data we discuss are from repeated semi-structured interviews with teachers and head teachers/senior managers in primary and secondary schools in Scotland. We use pseudonyms and description of role to identify the participants below.

While we will focus on individual teachers, their talk and the vocabularies that are deployed in their talk, it is of course important to bear in mind that such vocabularies are not invented by teachers but are the outcome of the complex interaction between personal sense-making and wider discourses that emanate from a range of different sources, including policy, research and public opinion (see, e.g. Nichols \& Griffith, 2009). As we will show in this contribution, some of these discourses are powerful because they are part of the official 
structures and cultures within teachers work, such as, for example, discourses about (measurable) student achievement. Other discourses are powerful because they are fashionable within educational circles, such as, for example, the'new language of learning' (Biesta, 2006), where pupils and students have been redefined as learners, teaching has become the facilitation of learning and schools have been redesignated as learning environments and places for learning. The language of learning has been quickly co-opted in many educational circles and has put pressure on an older and in a sense more explicitly normative language of education, one in which the point of schooling is not defined in terms of facilitating students' learning, but where there is a clear engagement with the question of purpose, that is the question what the learning is supposed to be for (Biesta, 2015).

In the sections that follow, we intend to show how the ways teachers talk figures in their thinking and doing and how this reflects on their sense of agency. We do this through a thematic presentation of insights from the data analysis which will also allow us to show how the ways teachers talk 'in' and 'about' education is connected to their personal and professional experience and the wider discourses that have informed and shaped their personal and professional biography. This will also allow us to make visible how some of such discourses seem to support the ways in which teachers make sense of their practice, while others seem to interfere with and distort what they feel matters and should matter in education. In the concluding section, we summarize what we think that the exploration of teachers talk tells us about its role and significance for teachers' sense of agency and their potential achievement of agency.

\section{Talking about education: Rachael}

One crucial question in relation to the theme of this paper is what teachers actually talk about when they talk about education. How, in other words, do they see the 'project' of education and what do they think that the particular task of the school is? Not surprisingly, some teachers have a more articulate way to talk about this than others. Rachael, one of the primary teachers in our project, in response to our question about what education is for, said that it was 'for growing and living, for life'.

If we didn't have learning then you wouldn't be able to have the skills in order to survive in anything that starts from the basic skills you learn just as a baby. (...) Gradually growing up. And then it is obviously more advanced skills. [Rachael]

She did not think, though, that children would perceive it in this way as well.

(P)eople would not think it is education although, because learning is education. Children, I do not think would see the link. If they were doing something they would not think that they are necessarily having education. They think of education as anything that happened in school, like written things. [Rachael]

For Rachael there is, therefore, on the one hand a clear distinction between learning as something that can happen all the time and everywhere-'There is never a point when there is not learning happening' - and what the school is for, although it is interesting that in her way of talking, 'learning' is also what is key in the school. In response to the question what school is for, she said:

Well, the main thing you would come straight away is for learning. But not just academic learning. You are building them as individuals to know how to relate to others, how to socialise, interact.

To get them prepared for the wider world. [Rachael]

This wider world is particularly conceived in terms of the world of work, which, for Rachael, is an important element of the life for which schools should prepare children. 
And I probably just link it to [work] because you see life as well if you do not work then you are not going to be living much of a life cause you are not going to be making any money. So a lot of it is linked to work. [Rachael]

What is interesting in relation to the particular context of our research is that Rachael appears to have adopted the idea that Curriculum for Excellence marks a shift in thinking and doing from a focus on knowledge to a focus on skills. She not only sees a strong distinction between education focused on knowledge and education focused on life, but is also quite negative about the former, thus echoing a rather common [mis]perception that skills do not require knowledge or that having knowledge or being knowledgeable is devoid of any skills (on this see Gill \& Thomson, 2012).

Is it nice to learn things, facts, but that cannot be transferred. That is not going to help them when they leave school. (...) Whereas the skills that help them learn those things or do a certain activity in a certain way is what will help them in the future. [Rachael]

During the 6 years that she has been a teacher, she does see this as an important shift in her thinking and in her practice.

I supposed I have gradually changed in that way that, well I suppose because it is quite all about knowledge. You are not really thinking as much about the skills. (...) Cause you are busy wanting your end product from them. But really the process should take a lot longer'cause you should be teaching them the elements to put all together to make this final. So yeah, I do think it has changed. [Rachael]

\section{Talking about education: Eilidh}

The emphasis Curriculum for Excellence places on skills is also what Eilidh, another primary teacher we spoke with, mentioned as a key aspect of how it has 'landed' in her school. This partly has to do with the discourse of Curriculum for Excellence itself, though Eilidh also mentioned that in her school they had decided 'on about twelve skills we felt as a school, that if we can do these, then our children will leave [our school] as better people'.

Whereas, Rachael not only perceived Curriculum for Excellence in terms of a shift from knowledge to skills but also saw this as a desirable shift, Eilidh saw this far less as an opposition. In her view, 'as an educator you do need to teach the knowledge as well as the skills'. More generally, her talk was more detailed and perhaps we could also say that it was more nuanced-something that may have to do with the fact that she had been in education for a much longer period of time than Rachael (see the next section). Here is, for example, how she spoke about her task of being a teacher.

I think ... if I look at it I think it changes between primary one and primary seven. I think in primary one initially it is very much a nurturing and the rules of behaviour within a school have to ... you have to pull them back in some ways. It can't be free. An awful lot of them live outside, in their own society where they do what they want, when they want, how they want. And it is just to try and get them back into the fact that, 'no that is not it, we have our rules in here and you have to become a valued member of this school', but in order to do that there has to be respect shown and given.

So whereas by primary seven hopefully a lot of that has been instilled, but you have got the few, and it is a few, who are pulling against society even at ten, eleven years old. Fighting against it. It is them, it is a control thing and bringing them back and trying to ... But as an educator you do need to teach the knowledge as well as the skills. So as much as it is about teaching the skills so they can go out, there has to be certain amounts of knowledge. It is clichés, the 
relevance of it all. But I think if you do show them that, if you couldn't read, you can't go into the bus station and read the times of the trains, how are you going to find the times of the trains? You can't use your computer. It is about trying to show them that 'yes you might find it boring when I am doing this all about timetables, but actually here is the reason for it'. And I think we are beginning to do that a lot more. [Eilidh]

Whereas both Rachael and Eilidh connect the 'point' of education with future participation in society, including the world of work, Eilidh's account appears to have more detail. The fact that balance is important in her account is also reflected in the way in which she compared her own experiences at school with the current situation.

The only thing that I can remember from school, and it is such a long time ago from primary, would be the very definite mornings for maths and language work, and the afternoons for the fun activities. I think that what we have got now is far better. I think we integrate much more and the children who maybe won't succeed at the maths and language side of it will succeed in many other areas of the curriculum. I personally wasn't classed as a bright pupil because my English skills were not wonderful in primary. But we didn't do the gym, which I excelled in. We didn't do a lot of arty type things. But it was all very much on writing, reading and initially, once I moved up obviously ... but secondary school, I just remember it being extremely academic based. Sit down, get on with it, and if you could then you succeeded and if you didn't you went into some other form of employment. I suppose even in my day, moving out to another form of employment was still possible whereas nowadays it is much more difficult. [Eilidh]

\section{Age and generation: Rachael and Eilidh}

While it is difficult to pin down why the two ways in which these teachers talk differ, one important aspect seems to have to do with the fact that stems from different professional generations. Rachael had only been teaching for 6 years whereas Eilidh had been 'in the system' for nearly 30 years already_referring to herself as a 'crabbit old teacher'. There are two aspects that need to be taken into consideration here; one which we might call an age-effect - that is, the impact of having been around for a longer period of time-and the other a generation-effect, where Eilidh, in her own teacher education and in earlier stages of her career, may have been exposed to very different views about education and very different education practices.

The 'age-effect' is clearly visible in the following remark where Eilidh emphasizes that older ideas seem to be coming back.

I have seen, in teaching, the child centred, the integrated day, the whole class teaching, five to fourteen and then back round to this more child centred, integration on everything again. They always do say that you come round in circles. And that is where I am now, thinking actually what I am doing now in primary one, because I started off in a primary one, a lot of similarities. [Eilidh]

Yet she is also aware that she has become more experienced and more confident over time.

I think I have become better. I think ... when I think back to some of the lessons I maybe did when I first started and I think'oh gosh, I didn't do that did I?' and I know we all learn by mistakes and sometimes it is no bad thing because then you can talk about it and discuss it, even with the children. But I think because you have made these mistakes you become a better teacher. I go to do something and then I don't have to think too much about it, because I think'that is not going to work, change it'. Whereas maybe twenty years ago, I would have tried it and it didn't work, so the next time I have not. [Eilidh]

Taking the impact of age/experience and generation together we can see that Eilidh has access to a discourse that gives her a 'bigger picture' and that allows her to put things in 
perspective. In this regard, we can say that Rachael seems to be more dependent on the policy discourse of Curriculum for Excellence, at least partly because she had not yet had the opportunity to experience and work through a series of policy-and practice-shifts and thus has had less opportunity to develop her discursive'resources'. What is clear from the discussion above is that such resources - more concretely, the way teachers talk about and understand education, the school and their role as a teacher-provide an important window on the situation they are in; a reflective window both to perceive and to evaluate what is going on and what is absent or missing.

\section{The personal and the professional: Shona}

Such discourses are, however, not just personal/biographical but are also related to the particular responsibilities one has as a teacher. They are, in other words, also a function of the particular ecological conditions of teachers' work. This is clearly visible in some of the ways in which Shona, headteacher of the primary school in our project, spoke about her work, the school and education more generally. On the one hand, her talk is obviously influenced by the particular set of responsibilities that come with the role, and thus they reflect some of the outside expectations and pressures quite well. This is first of all visible in how she sees her role within the school.

So I am responsible for absolutely everything. I am responsible for health and safety. I am responsible for the educational development of the pupils. I am responsible for all the legislative requirements that they have to implement to make sure that health and safety is in place. Additional support needs legislation is being followed. All the child protection stuff, assessments, risk assessments, educational excursions assessments, the whole quality assurance agenda, the provision of the curriculum, parental complaints, personnel issues, everything. [Shona]

Yet there is another side to her talk, which is visible in her views about good education where, as she put it, 'really just all hinges in terms of the catchment area'.

It is a very mixed catchment area. (...) I totally believe in the principles [in a policy document], which is about trying to break the cycle of deprivation within [the local authority]. And to ensure that pupils have the opportunity to maximise their potential. And to give them as much of a holistic approach, experience as possible so that they have the opportunity to experience success and to motivate and galvanise. And just break this whole cycle of deprivation. That is what I believe. [Shona]

While attainment matters in relation to such wider views about the point and purpose of education, it is clear that attainment is not an aim in itself, but in her view of education it serves a wider purpose. There is, in other words, a different 'story' about education that has a strong motivating force. Interestingly, in this case it is connected to this teacher's own educational biography. When asked whether she believes that the school can indeed break the cycle of deprivation, she responded in the following way.

Well I came myself from an area that is considered to be a deprived area in [name of town]. I came from [name of area]. And my mother was a home help. My father was an electrician. They were very hardworking people. And I suppose I was quite fortunate in as much as I was an only child. So I never actually lacked anything. But the driving force for me was always that they had high values about education. Education was always seen as the way of getting a good job. 'And if you stick in at school you will get a good job'. And I always wanted to please and I wanted to make them proud of me so I worked hard. But I wanted this good job because I wanted to have a nice house and I wanted to have nice holidays. And this had all been indoctrinated in a way. 'You need to do this. You need to get a good job. You do not want to be working as a home help or doing what I have had to do, working in a factory. You need to work hard'. [Shona] 
These biographical experiences provide a strong educational 'story' that clearly impacts on how she looks at the present.

But if we replay that situation to this context just now, I am not sure that I would have been able to go to University because I would have had to make choices about big debts because they would not have been able to fund me. I know from my own personal experience that it costs a lot of money to educate a child at University. And it can go on for a long time. And I do not know how I would have been able to access that. I do not know enough about the system. I just know that for my daughter we did not get any help and we had to fund it all ourselves. And my mum and dad certainly could not have done that. So I suppose there must be ways round that. But it would mean that you end University having a huge amount of debt. And my mother and father do not like debt. So they might have been pushing me in other directions. More about trying to get a job with the qualifications that you get when you leave school. [Shona]

It is therefore not surprising that she believes 'that education can make a difference-otherwise I do not think I would want to be doing the job that I am doing'. Within her talk there is a strong emphasis on skills and on values-'Good positive values. Our school motto is respect'. While she sees the focus on skills as 'one of the big changes' brought about by Curriculum for Excellence, she emphasizes that in her school '(w)e have always taken the trouble to provide opportunities for pupils to develop the kind of skills and attributes required by Curriculum for Excellence', so in this regard she does not think'it is going to make a huge difference'.

\section{Talking about education: Suzie}

The way in which our research was designed-interviewing and observing teachers in different primary and secondary schools-makes it possible to see to what extent the vocabularies teachers utilize in their work are personal/professional and to what extent they are related to the particular ecologies in which they work, that is, the cultures and structures that shape their context for action. While we did notice differences, there are also many similarities when we focus on the ways in which the teachers from secondary schools spoke about education.

The conversations we had with Suzie, a senior manager at one of the secondary schools, provided a very clear example of what above we have termed the generation effect. The comparison between the past and the present was frequently depicted as a loss, thus indicating that things as they are nowadays were not as good as they were in the past.

For example, when talking about the tendency in education to measure and assess everything, she provided the following observation.

We have lost the capacity to explore. To feel our way because for whatever reason we have become less secure, less happy with that because perhaps other people are less happy with it. But for me real learning is about going into the unknown and feeling your way and seeing what you discover and making sense of it. And finding things that you certainly do not know before you start out with. But to me, too many people are not doing that [laughs]. [Suzie]

She actually saw this development itself as a difference between generations.

For some people in recent years, education has become much more of a job. Teaching has become much more of a job that needs to be done between your employed hours. There is much less of the Scottish approach to education that I came into education embracing and that I have never really lost sight of. And people of my generation in teaching, most would consider that you are educating the whole person. That you are coming from a position of teacher first, subject teacher second. [Suzie] 
Her own teacher education-which she did in the 1970s—-played a formative role in her professional formation and, once more, provides a deficiency perspective on present practices.

Perhaps it says something about our own University education. It certainly does in my case, I know that. That we did not see ourselves first and foremost as having to just deliver our own subject curriculum. We wanted to be part of a family in a school. We wanted to be part of a community and all that goes with that including the negative side of developing a community. And I do not see that in the same numbers as I did when I was a young teacher. [Suzie]

While she welcomed many more recent developments and initiatives, she was concerned about what teachers are doing with them and are able to do with them.

They are all fantastic initiatives. But no single one of them on their own is enough. They are all part of a teacher's toolkit if you like. But I am worried about that concept of toolkit. It is that that for me has made many staff think along the lines of being a practitioner simply thinking of themselves a jobbing teacher. [Suzie]

For Suzie, teaching is precisely not about the application of a toolkit, but is a craft that needs to be developed and refined through experience-a process that obviously takes time.

There is one further aspect of Suzie's talk that we wish to mention, as it is quite different from what most other teachers spoke about, and is also distinctively different from what policy seems to emphasize, that is, focusing on measurable outcomes. Suzie's talk highlights that education is a difficult process and necessarily has to be difficult.

The best learning happens after pain. It is about an intellectual pain. It is about recognising that this is not easy. And sometimes you have got to have the conversation that says, 'I am very sorry about this but that is not good enough. What you are doing is just not going to cut the mustard. And we do have to look. I will help you to come to terms with what that is but it is just not up to scratch. This is what needs to be done. Here is where we are. Why are you doing this'. You have to somehow or other encourage somebody to genuinely get to their soul. Without it everything is sitting on the surface. (...) Now my methods of teaching in a classroom have always been to try to encourage young people to come into touch with that soul, if you like. And without it really there is no real learning. (...) But it is painful. [Suzie]

For Suzie, this also has a lot to do with her agency, not least because to challenge and encourage students to stay with what is difficult requires conviction and a degree of courage. There is a clear decision point in relation to this.

So you decide, do you challenge that and take all the fall out that goes with that? Or do you go over the surface of it and just accept it? There are some people who will accept it. And there are some people who will say, 'my integrity stops me from being able to continue with that'. [Suzie]

She is aware that being principled about what matters in education makes the job less easy - 'in a way I give myself a lot of extra grief' is how she described it. And again she sees this more principled stance disappearing-again a loss in comparison to the past.

But the voice inside me, my educational voice, my experienced voice that tells me I have got to address this, means I take on the difficulty. And stirring up the puddle tends to mean it gets clearer in the end. But I do not know whether we live in a time now where many people are of that same opinion. And that people are looking for an easy life. I hear it here with people, 'how long have I got to go before I am home'. [Suzie]

\section{Policy discourses: Monica and Kate}

While Suzie's talk was quite elaborate and specific, other teachers in our research had a way of talking about education that was much closer to the policy discourse of learning and of 
skills. When asked, for example, what education is for, one of the other teachers responded in a way quite similar to what we have seen from one of the primary teachers.

It is to learn. To help children to learn. But I wouldn't always agree that you are only learning in school. I think people are learning all the time. (...) I think education is all about learning from each other as well as guiding children to learn new things. (...) I think probably when you come into teaching at first you think you teach a subject and that is it. Then I quickly realised that I am actually having to teach social skills here. I am having to teach children how to learn. How to use skills to help them learn. And I think I was probably quite naive when I came into teaching. I thought they would know to put a title at the top of the page, and the date, and that sort of thing. But it is all these little things as well that you are teaching them. Teaching them how to be organised. Teaching them how to have relationships, to have manners, to think ... [Monica]

If this answer to the question what education is for stayed quite close to the language of learning and of skills, another teacher in the same school articulated this differently.

Preparing the pupils for whatever they want to do and giving them choices and opportunities to do things that otherwise they would not do if they were not in education. To try and give them a broader outlook on life and different people and different ways of living and different things that they could do in the future. [Kate]

When asked whether education was about transmitting particular pieces of knowledge so that students can pass exams, Kate was quick to respond with a'No I do not think so', although she did acknowledge that it is 'what we are measured on', and that it is important for pupils in that 'if they have decided that they want to go a certain route, so say they decide they want to be a doctor, then obviously they do need to pass certain exams so it becomes much more about that'.

\section{Experience outside school: Susan}

One further point to mention is that both Monica and Kate had come to teaching later in their life. We mention this because having a career outside of education before becoming a teacher is the exception more than the rule. In this regard, it is interesting that in the group of teachers who took part in the project-who were teachers identified by their managers as being quite agentic - we had three teachers who had not followed the more standard career that takes teachers from school, to a degree, to teacher education and back into school. Perhaps this also explains why their talk about education was more limited and probably more influenced by current and recent policy than was the case with other teachers. This is not meant as a judgement about their vocabularies, but just as an observation. It may well be that, over time, these teachers will expand their professional discourse due to ongoing experience of working in education.

One of the teachers we interviewed in the other secondary school, Susan, also had a career outside of education before she entered the teaching profession. Susan's talk about education is an interesting mix of a more fashionable/contemporary language that sees education as being about 'encouraging the learner,',personalisation and choice', the teacher as 'a facilitator', 'skills for living, skills for life', and setting students on the road 'to fulfil their potential', and observations and ways of conceiving of education that are quite critical of how some of these ideas play out in Curriculum for Excellence and how education more generally seems to have drifted away from what matters to her.

Education has got less and less to do with the individual pupils. And it values individuality less and less. And it appears to me to have become more bureaucratic and top heavy. And when 
there is so little money available for education and the budgets are being cut, they are being cut in the wrong place. It is actually bodies in the classroom that is needed. Not at management and higher levels. And it is encouraging pupils to learn. And the people who encourage the learner are the ordinary teachers, the ones who enjoy doing what they do and inspire. And that is the role of a teacher; it is to inspire them to want to learn more. Not necessarily about the subject you are teaching but just to inspire them to learn anything. [Susan]

While on the one hand Susan saw education as a very individual journey, and whereas she recognized that this is a key idea in Curriculum for Excellence, she did not see a significant gap between theory and practice.

Personalisation and choice! That sounds brilliant but in actual fact that is not going to be what it is. It is going to be personalisation of choice of the teacher teaching the subject. Not the pupil. [Susan]

She expressed similar doubts about the idea that students should be responsible for their own learning because she believes that'they do not actually understand what responsibility for their own learning is, and they are not capable of managing it'. She describes the predicament in relation to this as follows:

And the more able pupils still want classroom teaching from the front. They want to have things written down. They want to be taught in the old established way of teaching. And that is what they want because they see that as their route to get to further education. The less able pupils prefer the less structure, but they are in actual fact the ones who are less able to manage their own learning. Yet that is where the focus is. [Susan]

Also, while she was aware of the influence of testing on the practice of education, she made a clear distinction between what is being tested and what matters for her, although she did encounter situations where she was'in the minority' as someone'actually who was teaching broadly, not just to the exam.' 'The reality', as she said, 'is we are judged by the end result of exams.' But this implies that significant achievements that fall outside of the scope of what is being examined are not really acknowledged, which was obviously a source of frustration for her.

I had a brilliant experience with a pupil through four, five, six years of somebody who is not achieving A grades and whatever. But you have seen them grow to be lovely human beings. (...) But that is not valued. That is not measurable in a league table. But the point where they have got to from when they come into you at age eleven or twelve, to the point when they leave at sixteen, seventeen or eighteen. There can be a huge development that is not measurable on an education statistical table. (...) But that is such an important part of growing up. [Susan]

While she felt restricted by the emphasis on exams and measurement, this didn't stop her from achieving what she set out to achieve which, 'on the whole', she believed she could. In this regard one restriction she experienced is time-there is not enough time to do everything she would want to do. Another interesting restriction she mentioned 'is actually the pupils themselves and their attitude to learning in that they can be quite put off learning by previous experience.' She explained her own ability to navigate these complexities in terms of her personality. '(It) is because of who I am. It is because I grab opportunities and run with them'. This is a pattern she didn't always see in other teachers. Some teachers, according to her, 'are not willing to take risks' and the main reason for this lies in 'reliance on exam results and the need to provide evidence-and the evidence of a written piece of work is seen as of more value than something that might be a wall display or powerpoint presentation'. In her view this has affected teachers' confidence: 'Our confidence has been eroded'. 
Susan's talk appears to be 'mixed', but it is one that effectively allows her to have a critical perspective on Curriculum for Excellence, in that she is able to indicate where the curriculum really matches up with her own views about what matters educationally, and where there are tensions. There are therefore discursive resources that allow her to take a stance towards the prevailing policy - to judge what makes sense and what not. While she does explain her agency predominantly as a personality trait - the kind of person she is - this does not preclude the fact that she has a way to talk about education that not only gives her a drive and sense of direction (the projective dimension) but also allows her to evaluate situations she encounters (the evaluative dimension) and to act on the basis of these evaluations (the practical-evaluative dimension). What is less visible, at least in the data available, is what the origins of her educational discourse were (the iterational dimension).

\section{Shaping an educational outlook: Sara}

Sara, one of the other teachers we interviewed in this school provided some more insights into what had shaped her educational outlook, perhaps less so in terms of her educational vocabulary, but definitely in terms of what it means to do a job well, something which she connected to the working class background in which she grew up. Here is how she provided an insight in these experiences.

My dad was and still is a lorry driver, my mum was a dinner lady and she is now a receptionist. And they were just very much 'you work hard, you do what your teachers tell you.' And that was it. 'I am stuck with my homework', 'right, let's sit down and go over it' and they would help. But they were not pushy. They were there and they supported and encouraged but they never said, 'right, we want you to get five highers and we want you to go to University'. (...) And then when I said, 'I want to go to Uni'.'Right, fine, okay. We will help you'. Chose my Uni, went to Uni. 'Want to be a teacher.' 'Right, fine'. It was more just 'you work hard, you do as you are told, you give your best'. And because both myself and my brother went down different routes in life and they were always just of the opinion, 'we will support you in whatever way you go'. [Sara]

Not only did this attitude provide her with a set of strong values that gave her own work direction (the projective dimension), it also provided an orientation for her teaching. As for her own perspective, she summarized it as follows:

You just do a good job. You try your best. You do not muck around. You do not do things you should not do or challenge superiors in a way unless it's obviously something genuine. [Sara]

To which she then added:

And that is what I try and get across to the kids. You work hard and you do what you are told and you act on the advice you are given. You do not try and cheat or shortcut or squirm your way out of things. If you are struggling, you ask for help. [Sara]

This discourse is actually quite important for her, in that it shapes what she finds important in teaching, both in terms of what she seeks to achieve (the projective dimension) and in terms of how she views and values the situations she encounters (the practical-evaluative dimension).

As I say, there are some kids in our classes that are looking for a shortcut. And'can I not drop this, can I not .... And you are just like 'no. It's a pressure point. You are going to just have to make your peace with that and realise okay for about the next month or two I am going to have to just really really work. But then at the end of that month or two you have got your summer holidays. There is the reward. You get time off and you can do whatever you like'. [Sara] 
That this outlook does provide her with a perspective to judge what she encounters in the present is clear in the following quote.

But yes there are kids that don't have that mentality. And it is annoying sometimes because it is like the more and more they switch off or detach, the more and more stressed you get. And you think, 'wait a minute, I am not the one doing the exam'. [Sara]

Providing students with structure and a steady 'push' are important in her conception of education, as is also evident in the following passage, where she recounts how, in the longer term, the students are able to see the benefits of this approach. When asked whether she thought she was able to enact these views in the classroom, she said:

I try to. I really do try. And I think that there are kids that can see I have managed to influence them in a positive way because I try to just say to the kids, 'you know how I always get slagged off for being the organised one and the tidy and all of that'. And I am just like, 'but you have got one whole year's worth of work to wade through for your exam. And the worst thing ever would be if this was like you had a bit of that topic in that folder and a bit of that, and it was all over the shop. So if you start off in an organised way come revision time, everything is there. You are not going to have to have that battle.' And I say to them, 'I know I am the crazy stationery lady. Like how you get crazy cat ladies, I am the crazy stationery lady' [laughs] but there have actually been kids who have said to me, if I had not shown them how to do that, they would have just been an absolute nightmare. But even things as well like when they are doing $\mathrm{NABs}^{2}$ or their prelims $s^{3}$ and I am saying to them, 'just because this is not going to the [exam board], do not just opt for your minimum. Show off, do the best that you can'. [Sara]

Here we can see an articulate educational vocabulary, a way of talking and reasoning that gives a strong sense of direction to the practice of this teacher. What is interesting, however, is that there is a clear difference between the places where she feels able to act on the basis of her convictions and ideas and the places where she feels limited in doing so-which again sheds some light on the ecological conditions of the achievement of agency. Where she does feel there is a space for acting on the basis of her ideas is in her own classroom. When we suggested that we felt that she was 'fairly autonomous' in her own classroom, she immediately responded by saying 'oh yes, in my own classroom, absolutely-yes, definitely'.

And even in the department in terms of [our subject area], yes. And I work with people in my department who think the same way. Like we were talking about [a colleague] last time. So yes it is dead easy there. And on another angle, in the faculty, I am lucky enough to work in a faculty where the leadership has not gone the opposite way and where everything is controlled. [Sara]

So from this angle it looks like she acts in a situation where it is possible to achieve agency, where it is possible to enact a conception of education that clearly matters to her. But this is not all she has to say about it, because when asked about the presence or absence of synergy between her own views and the beliefs and vision of the school, she is more hesitant. The first response to our question here was a 'Mmhmm' and after an 'okay' from us a'yes' and a laugh.

There is [sic] different levels of tension. There is one level even within the faculty, I am trying to be very diplomatic here, I will look at certain things and I will think, 'that is really important. That ought to be done properly and it is not being done properly'. And in my head I will think how I would do it. But obviously I am powerless. [Sara]

That in this context she feels that she is powerless, indicates that the achievement of agency is not just a matter of capacity or having a clear discourse and a clear sense of direction and of what matters, but is always achieved-or not-in concrete ecological conditions. And whereas at classroom and, to some extent, at faculty level these conditions seem such that 
it is possible to achieve agency, within the wider context of the school this obviously becomes more challenging.

\section{Discussion and conclusions}

In this paper, we have sought to explore the discursive resources that play a role in teachers' achievement of agency. We have tried to characterize the different ways in which the teachers in our project spoke about their practice; we have tried to find out where such talk comes from, including the wider discourses that inform and shape teachers' talk; and we have tried to shed light on the ways in which their talk plays a role in the achievement of agency. A couple of things stand out.

One is that all teachers do have something to say about education, but that some talk is (far) more elaborate and detailed than other and that the different ways in which teachers talk about education reveal different 'strengths' of conviction. In each case, we have seen how the teacher's talk allowed them to have views about the current situation, which has to do with the practical-evaluative dimension of the achievement of agency. In some cases, there was little difference between teachers' talk and the prevailing situation, whereas in other cases there was a significant difference between how the teachers spoke about education and the situations they found themselves in. This at least allowed them to be critical about the current situation, though we have also seen how for some teachers this 'translates' into possibilities for action closer to their own values and convictions. Whether it allows teachers to act differently-and hence to achieve agency-is, however, not only dependent on a critical outlook and a vocabulary that provides an evaluative window on the situation, but remains dependent on the particular ecological conditions under which they act, something that some of the teachers we spoke with in our project were acutely aware of.

Zooming in on teachers talk also made it possible to get a sense of where their talk and their wider vocabularies came from. Here we found a clear biographical dimension, not only in how teachers viewed education but also with regard to their educational values. There was also clear evidence of age-effects - the influence of experience-and generation-effects - the influence of having had experience of very different contexts, practices and ideas, than what currently is prevalent. With some of the teachers this led to a stronger orientation towards the future (the projective dimension of agency) which did appear to make a difference with regard to teachers' actions in the here and how. What was interesting with one of the teachers in the secondary school was that the degree in which she saw herself as being able to achieve agency significantly depended on context-she felt more able within the environment of her own classroom, and felt less able ('powerless') within the wider context of the school.

Finally, we also found clear evidence of the influence of policy discourses-not least the discourse of Curriculum for Excellence itself-and wider trends, including many traces of the 'language of learning'.

What our research suggests is that the ways in which teachers talk in and about education is an important resource with regard to their achievement of agency. Teachers' talk, that is, the vocabularies they utilize they when articulate their views about education and their values and visions about what education ought to be, provides an important 'window' on the here and now, that is, on the everyday situations in which teachers act. Here, we can see that the degree to which teachers' vocabularies allow for a perspective on those situations 
plays an important role in their perceived room for manoeuvre, both because it allows for evaluation of the current situation (the evaluative dimension) and for a sense of alternative ways of acting (the projective dimension). Although teachers' talk and the vocabularies they utilize are first of all 'of' the teachers, it is also clear that such talk is not uniquely individual, but is to a degree shared because it emanates from shared histories and because it functions within shared practices. To this comes the fact that teachers' talk is not independent from policy, research and everyday discourses about education, both discourses from the past and discourses from the present.

Perhaps the most striking finding from our research is the degree to which the talk and vocabularies of some teachers appeared to be rather limited and closely connected to policy discourses, hence leading to a situation where there is very little different between teachers' talk and the policy discourses within which they do their work, thus limiting their opportunities for critical evaluation and alternative courses of action. Although teachers' talk is at most a necessary condition for their achievement of agency-our ecological approach highlights that the achievement of agency emanates from the complex interplay of individual capacity and collective cultures and structures - the experiences of the teachers in our project did indicate that such talk can make a crucial difference for teachers' agency. This, in turn, suggests that enhancing the discursive resources of teachers-through initial teacher education and ongoing professional development-remains an important avenue towards a more agentic teacher profession.

\section{Notes}

1. In concrete actions all three dimensions play a role, but the degree to which they contribute varies. This is why Emirbayer and Mische speak of a'chordal triad of agency within which all three dimensions resonate as separate but not always harmonious tones' (Emirbayer \& Mische, 1998, p. 972; emphasis in original). In line with this, they propose the following definition of agency as 'the temporally constructed engagement by actors of different structural environments-the temporal-relational contexts of action - which, through the interplay of habit, imagination, and judgement, both reproduces and transforms those structures in interactive response to the problems posed by changing historical situations' (Emirbayer \& Mische, 1998, p. 970; emphasis in original). Agency, in other words, thus appears as a 'temporally embedded process of social engagement, informed by the past (in its habitual aspect), oriented towards the future (as a capacity to imagine alternative possibilities) and "acted out" in the present (as a capacity to contextualize past habits and future projects with the contingencies of the moment)' (Emirbayer \& Mische, 1998, p. 963).

2. National Assessment Bank tests, used for Higher courses to assess mastery of course content.

3. Preliminary examinations - a dress rehearsal for the real exam to be taken later in the year.

\section{Disclosure statement}

No potential conflict of interest was reported by the authors.

\section{Funding}

This work was supported by the UK Economic and Social Research Council [grant reference RES-000-22-4208]. 


\section{Notes on contributors}

Gert Biesta is Professor of Education and Director of Research in the Department of Education of Brunel University London, UK. In addition, he is part-time NIVOZ professor for Education at the University for Humanistic Studies, the Netherlands, and Visiting Professor at ArtEZ Institute of the Arts, the Netherlands, and NLA University College, Bergen, Norway. His work focuses on the theory and philosophy of education and the theory and philosophy of educational and social research, with a particular interest in questions of democracy and democratization. He has published widely on a range of educational topics and issues, including teaching, teacher education, curriculum, citizenship education, adult education, education policy and vocational education. His 2004 book, The Beautiful Risk of Education, won the 2014 Outstanding Book Award from the American Educational Research Association (Division B).

Mark Priestley is Professor of Education and Deputy Dean of the Faculty of Social Sciences at the University of Stirling. Additionally, he leads the Curriculum and Pedagogy Research Group in the School. His research interests relate to the school curriculum (especially curriculum change) and the professional work of teachers, and recent work has focused in particular on Scotland's Curriculum for Excellence, with critical analysis of the CfE model and empirical research around teachers' work as they develop the curriculum. His publications include the edited collection Reinventing the curriculum: new trends in curriculum policy and practice (with Gert Biesta) and Teacher Agency: An Ecological Approach (with Gert Biesta and Sarah Robinson), both published by Bloomsbury Academic. He is currently a council member, and Chair of the BERA Academic Publications Committee Robinson), both published by Bloomsbury Academic. He is currently a council member, and Chair of the BERA Academic Publications Committee for the British Educational Research Association (BERA),and Co-Convenor of the European Educational Research Association Network 3, Curriculum Innovation. He is a regular user of social media (blog at http://mrpriestley.wordpress.com/;Twitter @markrpriestley). Publications are listed at http://rms.stir.ac.uk/converis-stirling/person/11016.

Sarah Robinson is an associate professor at the Centre for Teaching Development and Digital Media at Aarhus University in Denmark. Sarah is an educational anthropologist whose research interests span from policy in practice, curriculum reform, education bureaucracy to teacher agency. Currently she is researching enterprise education as a method in the Humanities and Arts in Higher Education. she has research experience from Denmark, Scotland and Australia and has published widely to international audiences.

\section{ORCID}

Gert Biesta (D) http://orcid.org/0000-0001-8530-7105

\section{References}

Ben-Peretz, M. (2011). Teacher knowledge. What is it? How do we uncover it? What are its implications for schooling? Teaching and Teacher Education, 27, 3-9.

Biesta, G. J. J. (2006). Beyond learning: Democratic education for a human future. London: Paradigm Publishers.

Biesta, G. J. J. (2007). Why'what works' won't work. Evidence-based practice and the democratic deficit of educational research. Educational Theory, 57, 1-22.

Biesta, G. J. J. (2013). Knowledge, judgement and the curriculum: On the past, present and future of the idea of the practical. Journal of Curriculum Studies, 45, 684-696.

Biesta, G. J. J. (2015). What is education for? On good education, teacher judgement, and educational professionalism. European Journal of Education, 50, 75-87.

Biesta, G. J. J., Priestley, M., \& Robinson, S. (2015). The role of beliefs in teacher agency. Teachers and Teaching: Theory and Practice, 21, 624-640. http://dx.doi.org/10.1080/13540602.2015.1044325. 
Biesta, G. J. J., \& Tedder, M. (2006). How is agency possible? Towards an ecological understanding of agency-as-achievement (Working Paper 5). Exeter: The Learning Lives project.

Biesta, G. J. J., \& Tedder, M. (2007). Agency and learning in the lifecourse: Towards an ecological perspective. Studies in the Education of Adults, 39, 132-149.

Connelly, F. M., \& Clandinin, D. J. (1988). Teachers as curriculum planners: Narratives of experience. New York, NY: Teachers College Press.

Emirbayer, M., \& Mische, A. (1998). What is agency? The American Journal of Sociology, 103, 962-1023.

Eraut, M. (1994). Developing professional practice and competence. London: Falmer Press.

Fenstermacher, G. (1994). The knower and the known: the nature of knowledge in research on teaching. In L. Darling-Hammond (Ed.), Review of research in education (Vol. 20, pp. 3-56). Washington, DC: AERA.

Gill, S., \& Thomson, G. (2012). Rethinking secondary education: A human-centred approach. Harlow: Pearson.

Goodson, I., Biesta, G. J. J., Tedder, M., \& Adair, N. (2010). Narrative learning. London: Routledge.

Nichols, N., \& Griffith, A. I. (2009). Talk, texts, and educational action: An institutional ethnography of policy in practice. Cambridge Journal of Education, 39, 241-255.

Priestley, M., \& Biesta, G. J. J. (Eds.). (2013). Reinventing the curriculum. New trends in curriculum policy and practice. London: Bloomsbury.

Priestley, M., Biesta, G. J. J., Philippou, S., \& Robinson, S. (2015). The teacher and the curriculum: Exploring teacher agency. In D. Wyse, L. Hayward, \& J. Pandya (Eds.), The Sage handbook of curriculum, pedagogy and assessment (pp. 78-91). London: Sage.

Priestley, M., Biesta, G. J. J., \& Robinson, S. (2013). Teachers as agents of change: Teacher agency and emerging models of curriculum. In M. Priestley \& G. J. J. Biesta (Eds.), Reinventing the curriculum. New trends in curriculum policy and practice (pp. 186-206). London: Bloomsbury.

Priestley, M., Biesta, G. J. J., \& Robinson, S. (2015a). Teacher agency: An ecological approach. London: Bloomsbury.

Priestley, M., Biesta, G. J. J., \& Robinson, S. (2015b). Teacher agency: What is it and why does it matter? In R. Kneyber \& J. Evers (Eds.), Flip the system: Changing education from the bottom up (pp. 134-148). London: Routledge.

Priestley, M., Robinson, S., \& Biesta, G. J. J. (2012). Teacher agency, performativity and curriculum change: Reinventing the teacher in the Scottish curriculum for excellence? In B. Jeffrey \& G. Troman (Eds.), Performativity in UK education: Ethnographic cases of its effects, agency and reconstructions (pp. 87108). Painswick: E\&E Publishing.

Schön, D. A. (1983). The reflective practitioner: How professionals think in action. New York, NY: Basic Books. Schön, D. A. (1987). Educating the Reflective Practitioner. San Francisco, CA: Jossey-Bass.

Schwab, J. ([1970] 2013). The practical: A language for curriculum. Journal of Curriculum Studies, 45, $591-621$.

Shulman, L. S. (1986). Those who understand: Knowledge growth in teaching. Educational Researcher, $15,4-14$.

Verloop, N., Van Driel, J., \& Meijer, P. (2001). Teacher knowledge and the knowledge base of teaching. International Journal of Educational Research, 35, 441-461. 